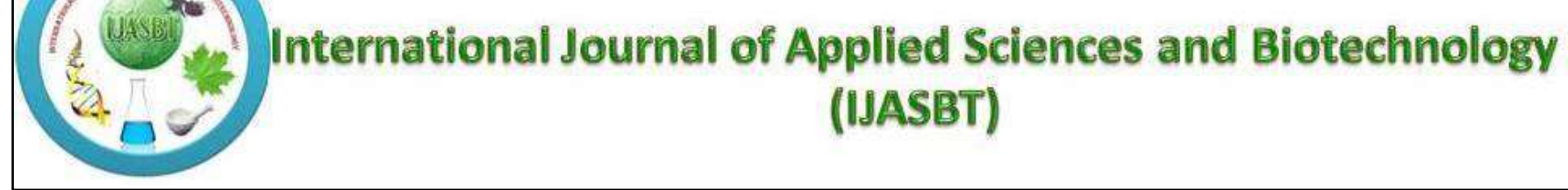

\title{
Effect of Replacement of Fish Meal by Soybean Meal on Growth of Oreochromis niloticus (Linné, 1758) Juvenile under High Temperature Treatment for Masculinization
}

\section{Charles Koffi Boussou ${ }^{1}$, Gustave Nguessan Aliko ${ }^{1}$, Nicole Ahou Yoboué1, Félix Koffi Konan ${ }^{1}$, Mamadou Ouattara $^{2}$ \& Germain Gourène ${ }^{2}$}

\author{
${ }^{1}$ Department of Environment, University Jean Lorougnon Guédé, BP 150 Daloa, Ivory Coast; \\ ${ }^{2}$ Department of Sciences and Environment Managment, University Nangui Abrogoua, 02 BP 801 Abidjan 02, Ivory Coast
}

Corresponding author's email: bkofficharles@live.fr

\begin{abstract}
Two experiments were conducted consecutively in triplicates to evaluate and compare the impact of different feeds on survival rate and growth performances of Oreochromis niloticus larvae during both the heat treatment for thermal masculinization and the subsequent juvenile stage. A commercial feed containing fishmeal with $32.38 \%$ crude protein (CFA) and an experimental feed with $25.48 \%$ crude protein (EFB) where fishmeal was entirely replaced by soybean meal were tested. In the first experiment, larvae of about 4 days post-hatch were reared for 21 days at a temperature of $36^{\circ} \mathrm{C}$ and the second has consisted in testing at ambient temperature the performances of these feeds on the previous fry for 70 72 days. Fish were fed four times a day ad libitum.

Results showed that there were no significant differences between growth performances (survival rate, final body weight, daily weight gain and specific growth rate) of larvae bred in hot water and nourished with feed containing fishmeal (CFA) or feed containing soybean (EFB) as protein source. However, better results were obtained with control batches bred at ambient temperature and fed with feed CFA or EFB. Postlarval rearing of previously heated fry showed that feed containing fishmeal has similar growth performances as feed containing soybean. Then, soybean meal can replace successfully fish-meal in diet of larvae during heating treatment for masculinization and also for the postlarval rearing of fry.
\end{abstract}

Keywords: Oreochromis niloticus; fry; feed protein; growth; high water temperature; masculinization

\section{Introduction}

Tilapias belong to the Cichlidae family, which is a group of warm water fish and have become the largest group of warm water aquaculture fish in the world (FAO 2003). In tilapia, sexual dimorphism for growth is largely well known (Baras \& Melard 1997) where males grow larger than females (Tave 1995). Therefore, the production of an all-male population is more profitable than a mixed-sex population. In recent years, much of the research has been conducted to develop techniques to produce all-male tilapia fry. The most important techniques are the production of a monosex population through hormonal sex reversal, interspecific hybridization and the production of genetically improved male tilapia (GMT) through breeding of YY "super-males" (Mair et al. 1991, Mair et al. 1997, Beardmore et al. 2001). Moreover, more recent studies provided evidence that water temperature also governed the phenotypic sex of genus
Oreochromis (Tessema et al. 2006; Wessels \& HörstgenSchwark 2007). It was found that high-temperature treatments (around $36^{\circ} \mathrm{C}$ ) during early developmental stage (labile period) cause a significant deviation of sex ratio in favor of males in Oreochromis niloticus (Baroiller et al. 1996a, b; Baras et al. 2001).

Fish growth is influenced by environmental, ethological, physiological and nutritional factors. However, temperature is recognized as one of the most important abiotic factors affecting growth, food intake and feed conversion (Martinez et al. 1996).

Many publications exist on the effects of water temperature on the growth and development of many fish species (ElSayed et al. 1996; Van Ham et al. 2003; Anelli et al. 2004; Campinho et al. 2004; Chatterjee et al. 2004; Larsson \& Berglund 2005). Most studies on Nile tilapia used fish at a 
late stage of development when factors other than temperature may have had permanent effects on growth characteristics (Hauser 1977; Platt \& Hauser 1978). At early stage of development in high supportable water temperature, no detailed information is available on interaction between feed component and growth of Nile tilapia.

The present study was carried out with two consecutive experiments, and aimed, in the first experiment, to determine the effect of feed protein source on growth and survival rates of Oreochromis niloticus fry in high water temperature, and in the second experiment, to assess the effect of protein source on the post heating growth of fry.

\section{Materials and Methods}

\section{Fish and Breeding}

The fish used in this experiment belonged to the 'Bouake' strain of Oreochromis niloticus from a farmed stock. Broodstock was composed of 3 males (mean weight $=200 \mathrm{~g}$ ) and 9 females (mean weight $=155 \mathrm{~g}$ ). Four spawners $(1$ male and 3 females) were stocked in mating aquaria of 120 litres. The three aquariums were provided with a continuous flow of dechlorinated filtered freshwater. Fishes were individually tagged in the dorsal musculature. Fecal matter removal was accomplished siphoning filtration in each aquarium. Supplemental aeration was provided to maintain dissolved oxygen levels near saturation with an aerator. Reproductions are detected by the appearance of maternal incubation behavior, which is highlighted by a characteristic dilatation of the females' mouth-pharyngeal cavity.

Three females were found mouthbrooding after respectively 16 and 17 days of mating. Their progenies were pooled together in another aquarium and treatments began three to four days post hatching. Experiments were conducted indoor.

\section{Diets Components}

Two diets were used for these experiments. CFF was a commercial fish feed with $32.38 \%$ crude protein containing fish meal as main protein ingredient. EFF was an experimental feed with $25.48 \%$ crude protein, formulated without fish meal, containing mainly soybean meal, cottonseed meal, maize bran, millet bran, vegetable oil, vitamin and mineral premix. Proximate nutrients composition of feeds is presented in Table 1 .

\section{Effect of High Temperature and Feed Contents on Larval Growth}

Twelve batches of 50 individuals were established from fry of 3 to 4 days post-hatching. Six fry batches were placed in plastic containers (4 liters) with a bubbler and a $1 \mathrm{~kW}$ immersion thermostatic heater; these containers were maintained floating in two 60 liters rectangular plastic tanks for the duration of the experiment. At the beginning of treatment, water temperature for each tank was progressively warmed to adjust and maintain the temperature at $36{ }^{\circ} \mathrm{C}$ at a rate of $1{ }^{\circ} \mathrm{C}$ per 2 hours in order to avoid thermal shock. The experimental temperature $\left(36^{\circ} \mathrm{C}\right)$ was maintained throughout 21 days (Baroiller et al. 1996a). Among the heated batches, 3 were fed with CFF (tank A1) and the 3 others fed with EFF (tank B1). The six remaining batches were placed in plastics containers with bubblers, without heaters and immersed in two 60 liters plastic tanks (tank A2, tank B2) and serve as controls. They were reared at ambient temperature for 21 days. About $30 \%$ of the water is renewed daily early before 6:00 h. Three batches (in tank A2) were fed with CFF and the 3 others located in tank B2 were fed with EFF. Then, each treatment is replicated thrice. Water temperature and dissolved oxygen were measured three times daily (8:00, 12:00 and 17:00 h) using an oxythermo-meter (AQUALYTIC sensodirect Oxy24). The fish were hand-fed daily 4-5 times ad libitum with powdered meal. At the end of the experiment, the thermostats were switched off and the tanks allowed cooling down progressively to room temperature.

During treatments, fry were observed daily and any deaths recorded. The final number of fry in each container was taken and recorded after 48 hours of post treatment. These values were used to calculate survival rates. Fish body weights were recorded to the nearest $0.001 \mathrm{~g}$ using an electronic balance (SARTORIUS) at the beginning and at the end of the experiment.

Table 1: Proximate nutrients components of feeds used for experiments. $\mathrm{CFF}=$ commercial feed containing fishmeal; EFF = experimental feed where fishmeal is entirely replaced by soybean.

\begin{tabular}{lllllll}
\hline Feed & Crud Protein & Crud fiber & Dry Matter & Crud fat & Ash & Protein Source \\
& $(\boldsymbol{\%})$ & $(\boldsymbol{\%})$ & $(\boldsymbol{\%})$ & $\mathbf{( \% )}$ & $\mathbf{( \% )}$ & $(\boldsymbol{\%})$ \\
\hline CFF & 32.28 & 7.28 & 88.58 & 7.51 & 9.99 & Fish meal \\
EFF & 25.48 & 9.34 & 90.61 & 7.13 & 15.38 & Soybean \\
\hline
\end{tabular}


Table 2: Mean initial body weight (MIBW) and rearing settlement of the second experiment. Ht_C = batch of fry previously bred in warm water and nourished with feed CFF; Ht_E = batch of fry previously bred in warm water and nourished with feed EFF; Control_C = batch of fry previously bred at ambient temperature and nourished with feed CFF; Control_E =batch of fry previously bred at ambient temperature and nourished with feed EFF.

\section{Batches}

\begin{tabular}{lllll}
\hline Parameters & Ht_C & Ht_E & Control_C & Control_E \\
$\mathrm{N}$ & 30 & 30 & 30 & 30 \\
$\mathrm{~T}^{\circ} \mathrm{C}$ & Ambient & Ambient & Ambient & Ambient \\
MIBW (mg) & $209,62 \pm 5,22^{\mathrm{a}}$ & $211,31 \pm 6,54^{\mathrm{a}}$ & $242,58 \pm 4,44^{\mathrm{b}}$ & $220,11 \pm 8,33^{\mathrm{a}}$ \\
Feed & CFF & EFF & CFF & EFF \\
\hline
\end{tabular}

Values (mean $\pm \mathrm{SEM}$ ) in the same line having different letters as exponent are significantly different $(\mathrm{P}<0.05$, ANOVA One Way test).

\section{Effect of Feed Contents on Growth of Previously Heated Fry}

Thirty fries from each batch were transferred in 120 liters aquarium 7 days after the end of experiment 1 . Initial conditions for the implementation of experimentation 2 are resumed in Table 2. Each batch was replicated thrice. The effective volume was about 100 liters. Fish were reared during 70-72 days. They were fed ad libitum thrice daily with the same feeds used during experiment 1. Water temperature and dissolved oxygen were measured three times daily $(8: 00,12: 00$ and 17:00h). About 50\% of the culture water was replaced with new water each two days. Each day, mortality was recorded. Fry were weighed to the nearest $0.001 \mathrm{~g}$ at the beginning and at the end of the experiment. Then, sexes of the whole fry per batch were determined through microscopic examination of gonads squash fixed in aceto-carmin (Baroiller \& Toguyeni 1996) at magnification 125 .

\section{Data Analysis}

At the end of each experiment, the means of final body weight (MFBW), daily weight gain (DWG), specific growth rate (SGR), survival rate (Surv_R) and final body weight coefficient of variation (CV_FBW) were determined. The following formulae were used:

\section{$D W G(g /$ day $)=(M F B W-M I B W) / d t, \quad($ Eqn. 1$)$}

where $\mathrm{dt}$ is the duration of the experiment in days, MFBW and MIBW are the mean final body weight and mean initial body weight respectively;

$S G R(\%)=\operatorname{Ln}(M F B W / M I B W) * 100 / d t \quad$ (Eqn.2)

Surv_R $=100 *$ final fish number/initial fish number (Eqn.3)

At the end of the second experiment, sex ratio (SR) per treatment was determined as percentage of males:

$S R=100 *$ number of males/total number of fish. (Eqn.4)

Data collected were subjected to statistical test using PAST

3.10 Software; mean, median and coefficient of variation were calculated by the software. Normality of growth parameters and temperature distributions was tested through Shapiro-wilk W test. When normality was assumed for all distributions compared, a one-way ANOVA was performed, if not, non-parametric Kruskal-Wallis test was done. Tukey's test and Mann-Whitney $U$-test were used for pairwise comparisons respectively as parametric and nonparametric tests. Differences were deemed to be significant at $\mathrm{p}<0.05$. The chi-square test $\left(\chi^{2}\right)$ was used to determine whether the observed sex ratio differed from the expected $1: 1$.

\section{Results}

\section{Effect of High Temperature and Feed Contents on Larval Growth}

Values of growth rate parameters, i.e. daily weight gain (DWG), specific growth rate (SGR) and mean final body weight (MFBW) and also water characteristics (temperature and dissolved oxygen) are summarized in Table 3. Dissolved oxygen mean values ranged from $3.65 \pm 0.96$ $\mathrm{mgL}^{-1}$ (Ht_E) to $4.98 \pm 0.88 \mathrm{mgL}^{-1}$ (Cont_E). It was significantly more high (Kruskal-Wallis, $\mathrm{p}<0.05$ ) in nonheated water tanks than in heated water tanks. Heated water batches mean temperatures $\left(36.21 \pm 1.94{ }^{\circ} \mathrm{C}-36.67 \pm 1.75\right.$ ${ }^{\circ} \mathrm{C}$ ) were significantly higher (Mann-Whitney $U$-test, $\mathrm{p}<$ $0.05)$ than control tanks water temperature $\left(28.77 \pm 1.31^{\circ} \mathrm{C}\right.$ $\left.29.19 \pm 1.38^{\circ} \mathrm{C}\right)$.

Most of the growth parameters showed similar values ( $\mathrm{p}>$ 0.05 ) between individuals reared in warm water at $36^{\circ} \mathrm{C}$ and fed either on feed CFF (Ht_C) or feed EFF (Ht_E) except specific growth rate that gave significantly highest values with CFF ( $p<0.05$ ). Besides, control larvae, reared in nonheated water, displayed values of growth parameters higher than those reared in heated water. The final body weight coefficients of variation revealed that heated larvae had more homogenous weights $(25.74 \pm 4.41-28.54 \pm 2.32 \%)$ than non-heated ones $(39.78 \pm 2.55-41.11 \pm 1.98 \%)$ at the end of experiment.

The mean survival rates were all more than $80 \%$ in all batches. Meanwhile, individuals reared in fairly cold water presented higher survival rates than those reared at $36{ }^{\circ} \mathrm{C}$. Indeed, survival rate of batches reared at ambient temperature and fed with feed CFF $(97.81 \pm 2.21 \%)$ was significantly higher (Mann-Whitney $U$-test, $\mathrm{p}<0.05)$ than that of the other batches. 
Table 3: Growth parameters of $O$. niloticus larvae reared at $36^{\circ} \mathrm{C}$ and nourished either with feed CFF (Ht_C) or feed EFF (Ht_E); control batches reared at ambient temperature; water temperature $\left(\mathrm{T}^{\circ} \mathrm{C}\right)$ and dissolved oxygen. [Mean Initial Body Weight (MIBW), Mean Final Body Weight (MFBW), Coefficient of variation of Final Body Weight (CV_FBW), Daily Weight Gain (DWG) and Specific Growth Rate (SGR)) and survival rate (Surv_R)]

\begin{tabular}{|c|c|c|c|c|}
\hline \multirow[b]{2}{*}{ parameters } & \multicolumn{4}{|c|}{ Treatments } \\
\hline & Ht_C & Ht_E & Control_C & Control_E \\
\hline MIBW (mg) & $11,81 \pm 1,44^{\mathrm{a}}$ & $12,11 \pm 1,81^{\mathrm{a}}$ & $12,36 \pm 1,12^{\mathrm{a}}$ & $12,21 \pm 0,98^{a}$ \\
\hline MFBW (mg) & $204,42 \pm 2,15^{\mathrm{a}}$ & $187, \pm 3,38^{\mathrm{a}}$ & $238,22 \pm 8,54^{\mathrm{b}}$ & $212,89 \pm 9,5^{\mathrm{a}}$ \\
\hline CV_FBW (\%) & $28,54 \pm 2,32^{\mathrm{a}}$ & $25,74 \pm 4,41^{\mathrm{a}}$ & $39,78 \pm 2,55^{\mathrm{b}}$ & $41,11 \pm 1,98^{b}$ \\
\hline DWG (mg/day) & $9,15 \pm 2,12^{\mathrm{a}}$ & $8,33 \pm 2,81^{\mathrm{a}}$ & $10,75 \pm 1,95^{\mathrm{b}}$ & $9,51 \pm 2,07^{\mathrm{a}}$ \\
\hline SGR $(\%)$ & $13,57 \pm 1,97^{\mathrm{b}}$ & $12,88 \pm 2,01^{\mathrm{a}}$ & $14,11 \pm 2,22^{\mathrm{c}}$ & $13,59 \pm 1,83^{b}$ \\
\hline Surv_R (\%) & $89,22 \pm 5,11^{\mathrm{a}}$ & $81,70 \pm 7,54^{\mathrm{a}}$ & $92,15 \pm 3,66^{\mathrm{a}}$ & $97,81 \pm 2,21^{b}$ \\
\hline $\mathrm{T}^{\circ} \mathrm{C}$ & $36,21 \pm 1,91^{\mathrm{a}}$ & $36,67 \pm 1,75^{\mathrm{a}}$ & $29,19 \pm 1,38^{\mathrm{b}}$ & $28,77 \pm 1,31^{b}$ \\
\hline Dissolved Oxygen (mg/L) & $3,97 \pm 1,06^{\mathrm{a}}$ & $3,65 \pm 0,96^{\mathrm{a}}$ & $4,55 \pm 0,74^{\mathrm{b}}$ & $4,98 \pm 0,88^{\mathrm{b}}$ \\
\hline Duration (days) & 21 & 21 & 21 & 21 \\
\hline
\end{tabular}

Table 4: Growth parameters of fry previously heated $\left(\right.$ at $\left.36^{\circ} \mathrm{C}\right)$ at larval stages and nourished with feed containing fishmeal (Ht_C) or soybean (Ht_E). Control_E and Control_C are control fry reared at larval stage at ambient temperature. [Mean Initial Body Weight (MIBW), Mean Final Body Weight (MFBW), Coefficient of variation of Final Body Weight (CV_FBW), Daily Weight Gain (DWG) and Specific Growth Rate (SGR)), survival rate (Surv_R), sex ratio (SR)]

\begin{tabular}{lllll}
\hline \multirow{2}{*}{ Parameters } & \multicolumn{4}{c}{ Treatments } \\
\cline { 2 - 5 } & Ht_C & Ht_E & Control_C & Control_E \\
\hline MIBW (mg) & $209,62 \pm 5,22^{\mathrm{a}}$ & $211,31 \pm 6,54^{\mathrm{a}}$ & $242,58 \pm 4,44^{\mathrm{b}}$ & $220,11 \pm 8,33^{\mathrm{a}}$ \\
MFBW (mg) & $10231,87 \pm 88,74^{\mathrm{b}}$ & $9741,58 \pm 12,59^{\mathrm{a}}$ & $7254,26 \pm 85,35^{\mathrm{d}}$ & $5781,12 \pm 35,63^{\mathrm{c}}$ \\
CV_FBW (\%) & $25,25 \pm 1,95^{\mathrm{a}}$ & $32,12 \pm 2,55^{\mathrm{a}}$ & $46,63 \pm 1,05^{\mathrm{b}}$ & $42,31 \pm 2,51^{\mathrm{b}}$ \\
DWG (mg/day) & $143,04 \pm 6,54^{\mathrm{a}}$ & $132,36 \pm 3,52^{\mathrm{a}}$ & $100,17 \pm 4,88^{\mathrm{c}}$ & $77,24 \pm 3,73^{\mathrm{b}}$ \\
SGR (\%) & $5,50 \pm 0,98^{\mathrm{a}}$ & $5,32 \pm 1,08^{\mathrm{a}}$ & $4,86 \pm 0,77^{\mathrm{c}}$ & $4,54 \pm 0,59^{\mathrm{b}}$ \\
Surv_R (\%) & $97,63 \pm 3,33^{\mathrm{a}}$ & $98,55 \pm 5,66^{\mathrm{a}}$ & $97,36 \pm 0,67^{\mathrm{a}}$ & $99,15 \pm 0,33^{\mathrm{a}}$ \\
SR (\% of Males) & $89,22 \pm 4,97^{*}$ & $97,25 \pm 2,01^{*}$ & $51,15 \pm 3,33$ & $48,33 \pm 6,67$ \\
T $^{\circ}$ C & $27,41 \pm 0,66^{\mathrm{a}}$ & $27,33 \pm 1,56^{\mathrm{a}}$ & $27,42 \pm 1,65^{\mathrm{a}}$ & $27,52 \pm 0,33^{\mathrm{a}}$ \\
Dissolved oxygen (mg/L) & $4,02 \pm 0,81^{\mathrm{a}}$ & $4,12 \pm 0,33^{\mathrm{a}}$ & $4,23 \pm 0,45^{\mathrm{a}}$ & $3,95 \pm 0,66^{\mathrm{a}}$ \\
Duration (days) & 70 & 72 & 70 & 72 \\
\hline
\end{tabular}

Values (mean \pm SEM) in the same line having different letters as exponent are significantly different $(P<0.05$, ANOVA One

Way test). *Sex ratio significantly different $(p<0.05)$ from the balanced (1:1) sex ratio according to $\chi^{2}$ test.

\section{Sex Ratio and Post-Larval Growth of Heated Larvae}

Table 4 presents results of experiment 2. Mean final weight ranged from $5781.12 \pm 35.63 \mathrm{mg}$ (Control_E) to 10231.87 $\pm 88.74 \mathrm{mg}\left(\mathrm{Ht}_{-} \mathrm{C}\right)$ and were significantly different $(\mathrm{p}<$ $0.05)$. The highest values were obtained with fry previously heated. Coefficients of variation showed that fish final weights were more homogenous $(\mathrm{p}<0.05)$ in previously heated larvae batches $(25.25 \pm 1.95 \%$ to $32.12 \pm 2.55 \%)$ than in control larvae batches $(42.31 \pm 2.51 \%$ to $46.63 \pm$ $1.05 \%$ ). Daily weight gain and specific growth rate showed the same trend, with highest values in batches heated at larval stages.

Concerning the effect of the different feeds on growth, the best performances were obtained with fry nourished with feed CFF, containing fish meal, in each group (previously heated and control at larval stages). Indeed, mean final weights in batches Ht_C (10231.87 $\pm 88.74 \mathrm{mg})$ and Control_C $(7254.26 \pm 85.35 \mathrm{mg})$ were significantly higher $(\mathrm{p}<0.05)$ than Ht_E $(9741.58 \pm 12.59 \mathrm{mg})$ and Control_E $(5781.12 \pm 35.63 \mathrm{mg})$ respectively. The others growth parameters, DWG and SGR gave the same trend. Survival rate $(97.36 \pm 0.67 \%$ to $99.15 \pm 0.33 \%)$, temperature $(27.33$ $\pm 1.56^{\circ} \mathrm{C}$ to $\left.27.52 \pm 0.33^{\circ} \mathrm{C}\right)$ and dissolved oxygen $(3.95 \pm$ $0.66 \mathrm{mgL}^{-1}$ to $4.23 \pm 0.45 \mathrm{mgL}^{-1}$ ) did not differ significantly among treatments $(\mathrm{p}>0.05)$.

The sex ratio was skewed significantly $\left(\chi^{2}, \mathrm{p}<0.05\right)$ in favor of males in all progenies reared at $36^{\circ} \mathrm{C}(89.22 \pm$ $4.97 \%-97.25 \pm 2.01 \%$ of males) during the larval stage. However those reared at ambient temperature at early stage showed sex ratios $(48.33 \pm 6.67 \%-51.15 \pm 3.33 \%$ of males) not significantly different $\left(\chi^{2}, \mathrm{p}>0.05\right)$ from the expected 1:1. 


\section{Discussion}

Results of experiment 1 (effect of high temperature and feed contents on larval growth) show that the growth performance and survival of fry at larval stages in warm water are not dependent of the feed quality. On the contrary, when larvae are reared at ambient temperature, growth performances are better with feed containing fish meal than those obtained with a food in which fish meal is replaced entirely by soybean. Meanwhile, previous studies of Bamba (2007) on larvae of Oreochromis niloticus at similar stages as the present study but at ambient temperature in concrete tanks outdoor didn't show significant differences in these feeds performances.

In the current study, at larval stages, better growth is obtained in general at ambient temperature (mean values $=$ $28.77 \pm 1.31-29.19 \pm 1.38^{\circ} \mathrm{C}$ ). The optimum temperature for feeding, growth and reproduction for this species is between 22 and $30{ }^{\circ} \mathrm{C}$ (Caulton 1982), while good growth was recorded in the upper portion of this range (Hauser 1977). Studies on several fish species have revealed that in the temperature range tolerated by fish, growth rates increase with increasing temperature and show a parabolic pattern (Xiao-Jun \& Ruyung 1992; Watanabe et al. 1993; Larsson and Berglund 2005). When experimental temperature reaches the upper extreme of the tolerance range, performance of growth decreases. Hence, the present study seems to indicate that temperatures around $36{ }^{\circ} \mathrm{C}$ decrease $O$. niloticus growth at larval stages. According to Azaza et al. (2008), this depression of growth could be due to the higher energy cost for maintenance metabolism and seems to be related mainly to a loss of appetite. The reduced growth performance at $36^{\circ} \mathrm{C}$ could also be attributed to the high rate of gastric evacuation, as reported by Elliot (1972), who observed a positive correlation between water temperature and the rate of gastric evacuation in fish. It has been suggested that higher temperature accelerates the rate of passing digesta through the intestinal tract, thus reducing the digestibility and assimilation of nutrients, signifying that at high temperature, physiological processes associated with digestion and nitrogen retention function are less efficient in fish.

Studies on post-larval growth of $O$. niloticus (experiment 2) revealed that previously heated fry grew faster than those reared previously at ambient temperature (controls). This result shows that heating fry at earlier stages of their life has no concerns on their subsequent growth performance. Furthermore, results on sex ratio have shown that heating larvae has biased sex differentiation towards males so that previously heated fry are almost monosex males. Indeed, in the present study mean sex ratios of larvae batches reared at $36^{\circ} \mathrm{C}$ ranged from 89 to $97 \%$ in favor of males. Several previous studies (Agienda et al. 2010; Wang \& Tsai 2000; Pavlidis et al. 2000; Desprez \& Melard, 1998; Baroiller et al. 1996a, b) have shown such results in O. niloticus.
Meanwhile, it is known that in Oreochromis niloticus, there is a differential growth in favour of males (Baras \& Melard 1997). That could explain the better growth performances of heated fry compared to non-heated ones in which males and females are theoretically in equal number. Indeed, in females there is a greater reallocation of metabolic energy towards reproduction, while in the males the metabolic energy is channelled towards growth (Caulton 1982). However, in the present study, individuals were not sexually active yet, so males' growth advantage could be due to the specific males' anabolism enhancing androgens as indicated by Fontainhas-Fernandes et al. (1994).

In the present study, fry fed with diet in which fish meal is replaced entirely by soybean meal (EFF) showed sometimes similar growth performances to those nourished with feed containing fish meal (CFF) which gave most of the times better results. This result suggested that soybean contained most of the necessary growth factors required by larvae under heated environment or by thermal sex reversed allmale tilapia.

Soybean meal has been widely used to replace partially or entirely the expensive fish meal protein diets in Oreochromis niloticus for many years (Ma et al. 1996; AbdElsamee et al. 2005; Bamba 2007). Then, according to the present study, soybean meal can replace successfully fish meal in diet of larvae during heating treatment for masculinization and also for the post-heating rearing of fry.

\section{Acknowledgements}

We would like to thank all the members of the Laboratory of Environment and Aquatic Biology of Nangui Abrogoua University for their help during experimentation. We are also particularly grateful to Professor Ouattara Allassane, Dr Bamba Yacouba, Kouman Y. Christine, Yao Ngodo Roger and the farmers' team from Blondey farm for their valuable contribution to this work.

\section{References}

Abd-Elsamee MO, Ibrahim MRM and Abd-Elkrim FM (2005) Use of some plant protein sources in broiler diets. Journal of Agricultural Sciences of Mansoura University 20(12): 7495-7506.

Anelli LC, Olle CD, Costa MJ, Rantin FT and Kalinin AL (2004) Effects of temperature and calcium availabilty on ventricular myocardium from the neotropical teleost Piaractus mesopotamicus (Holmberg 1887 Teleostei, Serrasalmidae). Journal of Thermal Biology 29: 103-113. DOI: $10.1016 /$ j.jtherbio.2003.12.001

Angienda PO, Aketch BO and Waindi EN (2010) Development of All-male Fingerlings by Heat Treatment and the Genetic Mechanism of Heat Induced Sex Determination in Nile Tilapia (Oreochromis niloticus L.). World Academy of Science, Engineering and Technology 4: 1-27.

Azaza MS, Dhraïef MN and Kraïem MM (2008) Effects of water temperature on growth and sex ratio of juvenile Nile tilapia 
Oreochromis niloticus (Linnaeus) reared in geothermal waters in southern Tunisia. Journal of Thermal Biology 33: 98-105. DOI: $10.1016 / j . j$ therbio.2007.05.007

Bamba Y (2007) Production en étang du tilapia Oreochromis niloticus (linne, 1758) nourri avec des sous-produits agricoles sans adjonction de farine de poisson. Thèse de doctorat unique de l'université Abobo-Adjamé, Côte d'Ivoire, 156p.

Baras E and Melard C (1997) Individual growth patterns of juvenile Nile tilapia Oreochromis niloticus (L.): emergence and dynamics of sexual growth dimorphism. In: Fitzsimmons K (Ed) Tilapia Aquaculture. Chapter 106, Northeast Regional Agricultural Engineering Service, 169-177.

Baras E, Jacobs B and Melard C (2001) Effect of water temperature on survival, growth and phenotypic sex of mixed $(\mathrm{XX}-\mathrm{XY})$ progenies of Nile tilapia Oreochromis niloticus. Aquaculture 192: 187-199. DOI: 10.1016/S0044-8486(00)00452-X

Baroiller J.F., Clota F. \& Géraz E. (1996b) Temperature sex determination in two tilapias species, Oreochromis niloticus and the red tilapia (Red Florida strain): effect of high or low temperatures. In: Goetz F and Thomas P (Eds) Proceeding of the Fifth International Symposium on the Reproductive Physiology of Fish. Austin, TX, 158-160.

Baroiller JF and Toguyeni A (1996) Comparaison des effets d'un stéroïde naturel, la $11 \alpha$-Hydroxy-androsténédione (11 $\alpha$ $\mathrm{OH}-\mathrm{A} 4)$ et d'un androgène de synthèse, la $17 \alpha$ Methyltestostérone (17 $\alpha-\mathrm{MT})$ sur le sex-ratio chez Oreochromis niloticus. In: Pullin RSV and Lazard J (Eds) Third International Symposium on Tilapia in aquaculture. Chapter 41, nov. 1991, Côte d'Ivoire. ICLARM Conf. Proc. 261-269.

Baroiller JF, Chourrout D, Fostier A and Jalabert B (1995) Temperature and sex chromosomes govern sex ratios of the mouthbrooding Cichlid fish Oreochromis niloticus. Journal of Experimental Zoology. 273, 216-223. DOI: $\underline{10.1002 / \text { jez. } 1402730306}$

Baroiller JF, Fostier A, Cauty C, Rognon X and Jalabert B (1996a) Effect of high rearing temperature on the sex ratio of progeny from sex-reversed males of Oreochromis niloticus. In: Pullin RSV, Lazard J, Legendre M, Amon kothias JB and Pauly D(Eds) Proceedings of the Third Symposium on tilapia in Aquaculture. Chapter 41, ICLARM Conference Proceedings, 246-256.

Beardmore JA., Mair GC and Lewis RI (2001) Monosex male production in finfish as exemplified by tilapia: applications, problems, and prospects. Aquaculture 197: 283-301. DOI: 10.1016/S0044-8486(01)00590-7

Campinho MA, Moutou KA and Power DM (2004) Temperature sensitivity of skeletal ontogeny in Oreochromis mossambicus. Journal of Fish Biology 65 (4): 1003-1010. DOI: $10.1111 / \mathrm{j} .0022-1112.2004 .00505 . \mathrm{x}$

Caulton MS (1982) Feeding, metabolism and growth of tilapias: some quantitative considerations. In: Pullin RSV and
Lowe-McConnell RH (Eds) The Biology and Culture of tilapias. ICLARM, Manila, Philippines, 157-180.

Chatterjee N, Pal AK., Manush SM, Das T and Mukherjee SG (2004) Thermal tolerance and oxygen consumption of Labeo rohita and Cyprinus carpio early fingerlings acclimated to three different temperatures. Journal of Thermal Biology 29: 265-270. DOI: 10.1016/j.jtherbio.2004.05.001

Desprez D and Melard C (1998) Effect of ambient water temperature on sex determination in the blue tilapia, Oreochromis aureus. Aquaculture 162: 79-84. DOI: 10.1016/S0044-8486(97)00242-1

Elliot JM (1972) Rates of gastric evacuation in brown trout, Salmo trutta (L.). Freshwater Biology 2, 1-18. DOI: 10.1111/j.1365-2427.1972.tb01575.x

El-Sayed AFM, El-Ghobashy A and Al-Amoudi M (1996) Effects of pond depth and water temperature on the growth, mortality and body composition of Nile tilapia, Oreochromis niloticus (L.). Aquaculture Research 27: 681-687. DOI: 10.1111/j.1365-2109.1996.tb01303.x

FAO (2003) Etat de l'Aquaculture dans le monde. Circulaire sur les pêches, 886, rév. 2, 114p.

Fontainhas-Fernandes A, Gomes E, Reis-Henriques MA and Coimbra J (2002) Plasma thyroid hormones and hepatic nucleic acids in relation to sex of tilapia Oreochromis niloticus. Journal of Applied Ichthyology 18: 185-191. DOI: $\underline{10.1046 / j .1439-0426.2002 .00329 . x}$

Hauser WJ (1977) Temperature requirement of tilapia. California Department of Fish and Game 63 (4): 228-233.

Larsson S \& Berglund I (2005) The effect of temperature on the growth energetic, growth efficiency of Aractic charr (Salvelinus alpinus L.) from four Swedish populations. Journal of Thermal Biology 30: 29-36. DOI: 10.1016/j.jtherbio.2004.06.001

Ma CY, Liu WS and Kwok F (1996) Isolation and characterization of proteins from soymilk residue (Okara). Food Research International 29: 799 - 805. DOI: 10.1016/09639969(95)00061-5

Mair GC, Abucay JS, Skibinski DOF, Abella TA a and Beardmore JA (1997) Genetic manipulation of sex ratio for the largescale production of all-male tilapia, Oreochromis niloticus. Canadian Journal of Fisheries and Aquatic Sciences 54: 396-404. DOI: 10.1139/f96-282

Mair GC, Scott AG, Penman D, Beardmore JA and Skibinski DOF (1991) Sex determination in genus Oreochromis: sex reversal, gynogenesis and triploidy in O. niloticus (L.). Theoretical and Applied Genetics 82: 144-152. DOI: 10.1007/BF00226205

Martinez CAP, Cristina CS and Ross LG (1996) The effects of water temperature on food intake, growth and body composition of Cichlasoma urophthalmus (Gunter) juveniles. Aquaculture Research 27: 455-461. DOI: 10.1111/j.1365-2109.1996.tb01275.x

Pavlidis M, Koumoundouros G, Sterioti A, Somarakis S, Divanach $\mathrm{P}$ and Kentouri M (2000) Evidence of Temperature- 
Dependent Sex-Determination in the European Sea Bass (Dicentrarchus labrax. L). Journal of Experimental Zoology 287: 225-232. DOI: $\underline{10.1002 / 1097-}$ 010X(20000801)287:3<225::AID-JEZ4>3.0.CO;2-D

Platt S and Hauser WJ (1978) Optimum temperature for feeding and growth of tilapia. Progressive Fish-Culturist 40 (3): 105-106. DOI: $\quad \underline{10.1577 / 1548-}$ 8659(1978)40[105:OTFFAG]2.0.CO;2

Tave D (1995) Production of all-male Tilapia aurea sex-reversed broodstock. Aquaculture 133: 78-81.

Tessema M, Müller-Belecke A and Hörstgen-Schwark G (2006) Effect of rearing temperatures on the sex ratios of Oreochromis niloticus populations. Aquaculture 258: 270-277. DOI: 10.1016/j.aquaculture.2006.04.041

Van Ham EH, Berntssen HG, Imsland AK, Parpouna AC, Bonga EW and Stefansson SO (2003) The influence of temperature and ration on growth, feed conversion, body composition and nutrient retention of juvenile turbot (Scophthalmus maximus). Aquaculture 217: 547-558. DOI: $10.1016 / \mathrm{S} 0044-8486(02) 00411-8$
Wang LH and Tsai CL (2000) Effects of temperature on the deformity and sex differentiation of tilapia Oreochromis mossambicus. Journal of Experimental Zoology 286: 534 537. DOI: $\quad 10.1002 /($ SICI $) 1097-$ $\underline{010 X(20000401) 286: 5<534:: A I D-J E Z 11>3.0 . C O ; 2-2}$

Watanabe WO, Ernst DH, Chasar MP Wichlund RI and Olla BL (1993) The effects of temperature and salinity on growth and feed utilization of juvenile, sex-reversed male Florida red tilapia cultured in a recirculating system. Aquaculture 112: 309-320. DOI: $10.1016 / 0044-8486(93) 90392-C$

Wessels S and Hörstgen-Schwark G (2007) Selection experiments to increase the proportion of males in Nile tilapia Oreochromis niloticus by means of temperature treatment. Aquaculture 272: 580-587. DOI: $\underline{10.1016 / j . a q u a c u l t u r e .2007 .08 .009}$

Xiao-Jun X and Ruyung S (1992) The bioenergetics of the southern catfish (Silurus meridionalis, Chen) growth rate as a function of ration level and temperature. Journal of Fish Biology 40: 719-7. DOI: 10.1111/j.10958649.1992.tb02619.x 